\title{
A Strategic Research on Young Teachers in Colleges and Universities to Raise Their Enthusiasm for Social Service
}

\author{
Wangfang Mao \\ Office of Party and Government Affairs, Southwest University, Chongqing, China \\ Email: mwf4938313@126.com
}

How to cite this paper: Mao, W. F. (2021). A Strategic Research on Young Teachers in Colleges and Universities to Raise Their Enthusiasm for Social Service. Creative Education, 12, 2905-2914.

https://doi.org/10.4236/ce.2021.1212217

Received: November 22, 2021

Accepted: December 25, 2021

Published: December 28, 2021

Copyright $\odot 2021$ by author(s) and Scientific Research Publishing Inc. This work is licensed under the Creative Commons Attribution International License (CC BY 4.0).

http://creativecommons.org/licenses/by/4.0/ (c) (i) Open Access

\begin{abstract}
With the acceleration of the new round of scientific and technological revolution and industrial revolution, higher education has entered a new stage of high-quality development, which undoubtedly puts forward new requirements and new tasks for the social service of modern colleges and universities. In order to further stimulate the enthusiasm and creativity of social services in colleges and universities, and explore the path of high-quality development of social services in colleges and universities, this essay focuses on young teachers, an important body of social service functions in colleges and universities, systematically using literature research, questionnaires and descriptive research methods to conduct research. The essay has discussed the importance of promoting them to engage in social services from four aspects, clarified issues in participation in social services and explained the root of problems from internal, external and other perspectives. Based on this multi-directional analysis, it has proposed feasible measures to raise the enthusiasm of young teachers in colleges and universities to participate in social services: strengthen guidance and change thoughts, improve systems and remove obstacles in systems and mechanisms and construct platforms as smooth participation channels.
\end{abstract}

\section{Keywords}

Innovation-Driven, Young Teacher, Social Service, High-Quality

Development, Connotative Development, Achievement Transformation

\section{Introduction}

Colleges and universities are the significant integration of science and tech- 
nology, the primary productive force, talented personnel, the primary resources and innovation, the primary driving force. As an important function of modern colleges and universities, social service plays a strategic supporting role in the national innovation system. In the 2020 China State Science and Technology Awards, colleges and universities (including affiliated hospitals) won 165 awards as the unit of the first accomplisher or the first accomplisher, accounting for $62.5 \%$ of the total number of awards, and 212 awards as the unit of the main accomplisher or the main accomplisher, which account for $80.3 \%$ of the total number of awards. Meanwhile, young teachers are inexhaustible source of ideas among teacher teams in higher education and are backbone of scientific research and technological innovation. They occupy a significant position in performing the function of social service, and they should play a greater role in serving the national strategy and local economy and society.

However, although there are numerous research literatures on social service in colleges and universities at home and abroad, few researches focus on young teachers. The current research status in China is as follows.

Firstly, since the implementation of the Innovation Ability Promotion Plan of colleges and Universities in 2013, the collaborative mechanism of industry-university-research has become a research hot spot in the academic circle. Therefore, the research on the collaborative innovation mechanism between the government, universities, society and enterprises is very rich for the better realization of the social service function of colleges and universities. Secondly, in the context of innovation-driven development strategy, academic research on social service innovation in colleges and universities has begun to increase. Whereas, the research is still in the initial stage generally, which is not closely related to the reality and cannot solve practical problems well. Thirdly, after the requirements of "convolution development of higher education" and "high-quality development of social economy" are put forward, studies on internal problems of colleges and universities often focus on the problems of teaching and management system of colleges and universities, such as, student training program and training mechanism setting and evaluation and transformation mechanism of scientific research achievements. The research seldom focuses on the responsible subjects, especially the teachers, with more professional knowledge and ability in social service than students.

Additionally, in the researches of scholars from other countries, there exist many successful cases that universities and colleges serve the society, the country and the industry through the transformation of scientific and technological achievements, while there are also few researches on young teachers.

Based on this, this paper starts from the subject of young teachers, analysing the reasons for their low enthusiasm, trying to put forward some measures that can effectively improve the enthusiasm of young teachers to participate in social service work in colleges and universities. 


\section{The Triple Significance of Young Teachers in Colleges and Universities Engaging in Social Services}

\subsection{The Participation of Young Teachers in Social Services Meets the Development Requirements of the Innovation-Driven Era}

Innovation is a vital force for the development of a country and a nation, and a major force for the development of the entire human society. Amid the accelerated formation of a new round of scientific, technological and industrial revolution, the restructuring of the global innovative domain has triggered the reconstruction of economic structure. The present world is undergoing major changes, which had never emerged in the history before. Countries around the world are paying more and more attention to the driving role of innovation in economic and social development.

In accordance with the "14th Five-Year Plan" for national economic and social development, China will implement the innovation-driven development strategy thoroughly, improve the national innovation system, and accelerate the building of a powerful nation of science and technology. Colleges and universities are the core of the knowledge innovation architecture and a major force of the technology innovation architecture, and social services are the important manifestation of the core competitiveness of colleges and universities.

Under the requirements of the innovation-driven era, colleges and universities are bound to give full play to their strengths in disciplines, talents, and technologies, promote innovations in theories, knowledge and techniques, expand their cooperation with society, realize deep integration of science, education and economy and effective integration of production, education and research, and urge the transfer and transformation of scientific and technological achievements. To serve the economic and social development more consciously and proactively has been an important mission of colleges and universities.

\subsection{The Participation of Young Teachers in Social Services Is a Subject Pertinent to Connotative and High-Quality Development of Colleges and Universities}

As a comprehensive concept, the "connotative and high-quality development" emphasizes the endogenous power to bolster development and its systematicness, agreement and sustainability. From the internal perspective, it refers to the governance capacity, development benefit, social contribution and international influence of colleges and universities.

"First-class university" should pursue first-class level in all aspects. To be specific, it should cultivate first-class talents, create first-class disciplines, produce first-class results and provide first-class social services. To measure the quality of a university, whether to value, guide and promote its participation in social services has become an important indicator. For example, in the University Research Excellence Evaluation System (REF) launched by the Higher Education Funding Council for England and other institutions, the non-academic influence 
of a university, including its impact on economy, society, culture, public policy, innovation ability and other aspects, accounts for $20 \%$ (Hou, 2019).

In the Reform of Educational Evaluation promoted by the Chinese government vigorously, the evaluation of universities has strengthened the social service function, contribution and social impact of disciplines. As main body of the faculty of colleges and universities, young and middle-aged teachers are important pillar of talent training, scientific research and social service.

Therefore, only by raising the enthusiasm of young teachers for participating in social services can colleges and universities expand their main body of schoollocal cooperation and enhance the contribution and influence of their social services.

\subsection{The Participation of Young Teachers in Social Services Is a Significant Approach for Their Growth and Accomplishment}

Firstly, different from passive training and other methods, social service can be regarded as an "active platform" for the growth of young teachers in colleges and universities. Because young teachers are active subjects in social services, they can combine learning with use. Meanwhile, based on their higher enthusiasm and initiative for learning, young teachers can upgrade their professional knowledge and practice level quickly.

Secondly, social service is conductive to raising the teaching and scientific research level of young teachers. By use of social service projects or platforms, they can deep into the front line of production, conduct scientific research activities in line with issues occurring in actual production. They can find more certain directions and more practical results, enrich teaching contents, reform teaching method and enhance teaching level, so as to form a virtuous circle of mutual promotion of teaching and scientific research.

Thirdly, social service is beneficial to boosting the innovation of young teachers. In the face of technical issues appearing in practice, teachers should apply their knowledge and skills flexibly to propose creative solutions, which can stimulate their inner motivation and potential to research and innovate.

\section{Status Quo and Issue of Young Teachers in Colleges and Universities Participating in Social Service}

\subsection{Fewer Participation Methods}

After investigating social services in domestic and foreign colleges and universities, the author has found that young teachers participate in such services through 7 major methods: firstly, individual research project, subject study of project team, or work entrusted by enterprises and public institutions to schools; secondly, project declared by schools, enterprises, local governments, etc.; thirdly, scientific and technological service and guidance provided by teachers on site; fourthly, achievement transformed and application promoted by teachers relying on transformation platforms of scientific and technological achievements; fifthly, 
patent and intellectual property right transferred by teachers to extra-school units; sixthly, strategic consultation for government decision-making and other development from teachers; lastly, assuming temporary posts in enterprises and public institutions, etc.

\subsection{Lower Degree of Participation}

According the investigation, the author has found that some young teachers in colleges and universities have insufficient enthusiasm and lower degree of participation in social services. Taking the author's university as an example, the number of young teachers under 35 who directly or indirectly participate in social services accounts for nearly $45 \%$ of all young teachers. The number of people who directly undertake scientific research projects entrusted by enterprises or the government is less than $30 \%$. The ratio of horizontal scientific research projects led by young teachers is about $30 \%$, and the project funding is relatively low.

\subsection{Unbalanced Participation Structure}

According to the research and development, discipline development, gender and entry time are factors affecting the degree of participation of young teachers in social services, reflecting some structural differences. From the perspective of discipline, young teachers of advantageous disciplines are more active and engaged in social services. From the perspective of gender, male young teachers are more involved than the females. From the perspective of entry time, the young teachers who have been employed for 3 - 5 years is more active than those who have been employed for 1 - 2 years. The longer the entry time, the higher the degree of participation.

\section{Factors Affecting the Enthusiasm of Young Teachers in Colleges and Universities to Participate in Social Services}

\subsection{Inadequate Understanding of Social Service}

On the one hand, some young teachers are affected by traditional educational thought of "emphasizing academics and despising application" deeply. They have formed an incomplete understanding of what social services are, why they should conduct social services and how to develop social services. Hence, they haven't paid enough attention to this work (Wang \& Shao, 2012). Some center on teaching and scientific research unilaterally. They believe that there is an antagonistic relationship among teaching, scientific research and social service. Under this circumstance, they regard social service as a dispensable work and a supplement to teaching and research-the principal work. In other words, social service is to make additional remarks to teaching and research, the present splendor. On the other hand, some young teachers separate social service from high-quality development of school. They fail to clarify the relationship between two sides and look at this issue from an isolated vision. Therefore, they fail to 
understand the importance of social service from the connotation construction and extensional development. From this, these young teachers lack initiative and enthusiasm for social service, much less the innovative work.

\subsection{Heavy Teaching Task and Research Pressure}

In general, young teachers are under great pressure from teaching, scientific research and survival. To begin with, teaching pressure. Under a relatively high student-teacher ratio, some colleges and universities are short of full-time teachers. As a consequence, young teachers not only need to teach many courses, but also guide students in internship, graduation thesis (design), innovation and entrepreneurship training and other academic tasks. Most of the young teachers under the age of 35 start to work in school after graduating from the master and doctor. Due to insufficient teaching experience, they require a lot of time for lesson preparation and self-improvement. Moreover, scientific research pressure. In many colleges and universities, the achievement of scientific research is directly linked to teacher's performance appraisal, evaluation of professional titles, allocation of subsidies for teaching and research, and enrollment of masters and doctors. Meanwhile, these schools have higher requirement for the achievement of scientific research. However, young teachers are still in the growth stage. So, they lack a research team and their foundation of scientific research is weak. To complete professional task and realize individual development, they have to spend a lot of energy in scientific research. Under this circumstance, no extra time is left for social service. Last but not least, survival pressure. Given that most young teachers are just entering the society, their wages are limited and their financial accumulations are weak. Faced with issues in dating, marriage, childbirth, house and vehicle purchasing, socializing and so on, they have to undertake many invisible pressures.

\subsection{Unsound Appraisal System and Incentive Mechanism}

Towards the evaluation of social service achievements, colleges and universities more or less value form and short-term result but belittle content and long-term result, simplify evaluation indicator and method, and concern utilitarian achievement. For example, in the performance appraisal of teachers, the percentage of social service score is relatively low. Similarly, during the evaluation of professional titles and the determination of enrollment for masters and doctors, there is a large gap between the evaluation of scientific research projects commissioned by enterprises and institutions and vertical scientific research projects. Colleges and universities have paid insufficient attention to achievement transformation, promotion and so on. Besides, they have gave limited rewards on social service achievements, which are far away from rewards on teaching and scientific research. Amid the evaluation criterion, young teachers are apt to focus on other aspects with higher performance and reward, which affects their enthusiasm of participating in social services. 


\subsection{Inadequate Individual Capability}

In the absence of practical ability and work experience, most young teachers who start to work in universities and colleges after graduation lack the ability to produce and transform research results, provide excellent scientific service or social training, or realize outstanding school site cooperation and social service, which is a widespread phenomenon. Some young teachers are immersed in scientific research and teaching. Under this circumstance, they are out of touch with the outside world. They know little about the international and domestic development situations, national and regional development policies, economic and social development trends, or industry and market demands. Such working status makes them confused about the direction and detail of social services, which results in limitation of their own services.

\subsection{Poor Participation Channel}

Given that some colleges and universities have little or no guidance for teachers to participate in social services, young teachers there have fewer channels to engage in them. Besides, most social services in colleges and universities are faced with low level, less output, poor integration effect and other issues. Hence, they are provided by teachers voluntarily rather than in an organized way. Moreover, there are few social service platforms built by colleges and universities themselves or jointly with enterprises and the government. In the absence of strong fund and policy support, no social service can be managed under the standardized system, causing practical difficulties for young teachers to engage in them.

\section{Strategies for Raising Enthusiasm of Young Teachers in Colleges and Universities to Participating in Social Service}

\subsection{Strengthen Guidance and Change Thoughts}

Among factors affecting young teachers to carry out social services, the key is whether teachers really realize the importance of social service ideologically. Therefore, it is necessary to strengthen publicity and education, and guide young teachers to join in social services through policy guidance, expert lecture, special training, demonstration and guidance, and atmosphere creation. By this way, young teachers may upgrade their awareness from social service work to the development of economy and society, promote the connotative development of higher education, and realize their own social value and individual growth. They may become an active bearer of social responsibilities from a passive performer of social obligations. Plus, it's necessary to lead young teachers to continue to upgrade their professional awareness of "self-development". Only in this way can they respond to social development and market changes quickly and effectively, take the initiative to undertake topics and service projects about enterprise and social application, consciously enrich their careers, maintain cooperative relationships with enterprises in the same industry, and make school-local cooperation and social service become one of the supporting points of teachers' 
career development.

\subsection{Improve Systems and Remove Obstacles in Systems and Mechanisms}

First, it's necessary to perfect management and operation mechanisms of social services in colleges and universities. To realize the centralized management and unified leadership of social services, colleges and universities should modify their top-level design of social services, establish a system of rules and regulations, solve issues of multi-head management, insufficient resource integration, lack of systems and so on in the development of social services, and strengthen the overall effectiveness of these services.

Second, it's necessary to reform the evaluation and incentive mechanisms of social service. To promote the reform of science and technology evaluation, colleges and universities should evaluate service quality, actual effect, economic and social benefit, and real contribution of teachers and scientific and technical personnel who are mainly engaged in school-local cooperation and social services. "Whether to promote economic development and social progress should be regarded as an important indicator for evaluating the level of science and technology. Meanwhile, the industrialization and socialization of achievements of scientific research are significant yardstick for measuring the quality of scientific research." (Xiang, 2012). Colleges and universities should implement the system of "Extension Specialist" and set up application-oriented position. They should perfect their methods of title evaluation and appointment, cultivate outstanding young talents with good development potential and who can grow into top-notch talents in social services, Moreover, they should develop a batch of young "backbones" for social services in an organized and planned manner. Colleges and universities should optimize their performance appraisal and distribution methods, give full play to the guiding role of the distribution system, and increase the scoring of horizontal cooperation projects towards the workload identification of scientific and educational personnel, performance appraisal and determination of enrollment indicators of masters, so as to gradually make no discrimination in vertical and horizontal projects of scientific research and increase the scoring for the promotion and transformation of scientific and technological achievements. Plus, colleges and universities should give rewards to units and individuals with outstanding contributions and achievements in the development of social services, especially the awards to young teachers.

Third, it's necessary to build a favorable interaction mechanism among social service, talent training, and scientific research. Colleges and universities should take the initiative to establish internship training bases for social service, regard social practice as an important indicator of student assessment, and take engagement in social services and guidance on social practice as a significant item of teacher assessment.

They should make best of principal role of social services in secondary colleg- 
es, strengthen innovative and practical education of young teachers, and further perfect the long-term mechanism of education, scientific research, close connection, constructive interaction and common development.

\subsection{Construct Platforms as Smooth Participation Channels}

First of all, expand social service channels in colleges and universities. Colleges and universities should keep up with major national and local construction plans and reform decision-making trends, and conduct in-depth investigation to grasp new requirements for talent training and scientific research derived from adjustment of industrial structures and implementation of major projects. Meanwhile, they should keep abreast of new progress of major national strategies and major projects, make scientific planning, try to expand resources of social service, strive for cooperation projects between themselves and enterprises and institutions, so as to provide teachers with channels, resources and opportunities of social services, the youth in especial.

Moreover, colleges and universities should encourage and assist teaching and research units to integrate superior resources inside and outside, and establish long-term and stable strategic partnerships with research institutes and enterprises.

Second, build platforms for collaborative innovation and industry-universityresearch cooperation. Universities and colleges should strengthen collaborative innovation among universities and research institutions, strengthen exchanges and integration among advantageous disciplines, encourage interdisciplinary research and cooperation, and carry out joint research (Cheng, Yang, Zhang, \& Mao, 2017). They should also adhere to multi-disciplinary integration, multiteam collaboration and multi-technology integration, form collaborative innovation research teams and build integrated platforms for scientific and technological innovation, so as to promote organic integration and full sharing of innovation factors. Cooperating with listed companies, large enterprises and leading enterprises in the industry, they are able to build enterprise technology centers, engineering centers, enterprise research institutes, engineering laboratories, etc. Hence, they, based on the industrial chain, can jointly carry out common key technologies to improve the independent innovation ability of enterprises and the applied research and development ability of schools.

Last but not least, special support will be given to young teachers to participate in social services. Colleges and universities may establish social service special funds for young talents and provide financial support for young teachers to engage in social services, and stimulate their enthusiasm and initiative. With the aim of encouraging teachers to engage in high-level transformation of scientific and technological achievements and services, they should gradually improve the service and support system for teachers' innovation and entrepreneurship and industry-university-research cooperation. For instance, they can establish the mechanism of information exchange and talent interaction between universities 
and enterprises. It is also feasible to improve the information supply and demand database of industry-university-research cooperation and build the information public service platform. In addition, establishing the information supply and demand database of cooperation is a good suggestion as well. Only then can they provide guarantee for young teachers to participate in social services successfully and thoroughly.

\section{Conflicts of Interest}

The author declares no conflicts of interest regarding the publication of this paper.

\section{References}

Cheng, L., Yang, M. H., Zhang, Q. Z., \& Mao, W. F. (2017). Analysis on the Optimizing Approach of Industry-University-Research Cooperation under the Innovation-Driven Development Strategy. Chinese University Science \& Technology, 3, 80-82.

Hou, D. K. (2019). Defining the First-Class University by Its Ability to Serve the Community. Science Times, 7.

Wang, C. F., \& Shao, J. D. (2012). Status Quo, Problems and Countermeasures of Teachers' Social Service Work in Higher Vocational Colleges. Modern Educational Science (Higher Education Studies), 9, 141-143.

Xiang, Y. P. (Ed.) (2012). Study on the Performance Evaluation of Socialization Service in Local Colleges and Universities. Chengdu: University of Electronic Technology of China Press. 